\title{
Choose the Right Citrus Rootstock ${ }^{1}$
}

\author{
William S. Castle, Stephen H. Futch, and Rhuanito Soranz Ferrarezi
}

After the arrival in 2005 of citrus greening disease, or huanglongbing (HLB), in Florida, making a profitable rootstock decision became more complicated. Previously, one could choose a rootstock based almost solely on yield, fruit quality and soil type. Now, despite increasing evidence suggesting that the choice of rootstock and scion variety may have a favorable impact on grove performance and financial outcomes in the presence of HLB, tree survival is also critical. New rootstocks are being developed and released for commercialization at an accelerated pace. Some of those rootstocks appear to offer a level of protection against HLB, but they have not had the same degree of field evaluation over numerous locations, years and sites as those rootstocks released prior to the HLB era. Today, the successful grower must be confident in managing HLB among young, nonbearing trees and later, and then choose rootstocks that have good horticultural traits sufficient to be profitable. Regardless of these changes, there remains a time-honored framework for selecting rootstocks.

Choosing a rootstock is an important decision because it is a relatively permanent one with long-term significance. The steps in making that decision may not always be obvious. For example, never underestimate your personal experiences along with that of friends, neighbors, and nursery managers. Anecdotal and personal observations may be conflicting and sometimes confusing, but the information can lead to better rootstock decisions. Some of the other steps and factors involved are described below in a generalized approach to selecting the best rootstocks for your conditions. The emphasis is on horticultural performance, not on HLB issues.

Note that any rootstock decision in the post-HLB era is necessarily riskier than previously simply because we do not fully understand interactions between the bacterium presumed to cause HLB and the rootstock itself.

\section{Gather the facts about the site and its history}

Consider as much factual information as possible. Doing so is especially critical in the post-HLB world. Performance information is limited for all rootstocks, but especially ones released in recent years. Rootstocks are no longer released after 20 years of field evaluation due to the urgent need for rootstocks that may offer some degree of improved HLB tolerance. Emphasis can be placed on:

\section{- Soil Chemical and Physical Traits; Site Characteristics.} Texture, depth to an argillic (clay) or spodic (organic) layer, organic matter content, $\mathrm{pH}$, water-holding capacity, drainage, depth to the water table, nutrient status, etc. Use the information in the USDA County Soil Survey. Aerial

1. This document is HS-932, one of a series of the Horticultural Sciences Department, UF/IFAS Extension. Original publication date June 2003. Revised August 2015 and September 2020. Visit the EDIS website at https://edis.ifas.ufl.edu.

2. William S. Castle, professor emeritus, Horticultural Sciences Department, UF/IFAS Citrus Research and Education Center; Stephen H. Futch, Extension agent emeritus; and Rhuanito Soranz Ferrarezi, assistant professor, UF/IFAS Indian River REC; UF/IFAS Extension, Gainesville, FL 32611.

Previous version: Castle, William S. and Ferguson, James J. (2003). Considerations for Choosing the Right Rootstock. Available online: http://ufdc.ufl.edu/ IR00007239/00001

The Institute of Food and Agricultural Sciences (IFAS) is an Equal Opportunity Institution authorized to provide research, educational information and other services

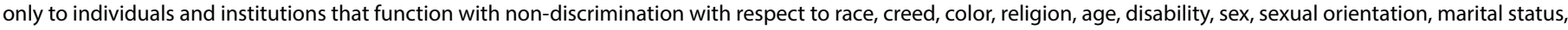

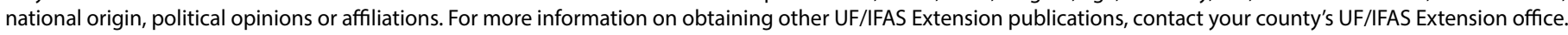
U.S. Department of Agriculture, UF/IFAS Extension Service, University of Florida, IFAS, Florida A \& M University Cooperative Extension Program, and Boards of County Commissioners Cooperating. Nick T. Place, dean for UF/IFAS Extension. 
images with soil data are available online along with descriptive documents of the soil series. They are quite valuable in showing site variations, especially those that existed before planting. The "poor" spots tend to persist in their effects in a grove, and in some cases, they are very difficult to overcome regardless of the level of inputs applied.

- Location. Special attention should be given to the abiotic (salinity, $\mathrm{pH}$, soil type, drainage, drought period and likelihood of freezing events) and biotic stresses (pests and diseases) related to the site (i.e. Flatwoods vs Ridge groves).

- Topography. Changes in elevation are important to both air and water drainage. Images showing elevation changes and other features are available on the internet. Visit the Florida Geographic Data Library (FGDL) at the University of Florida (www.fgdl.org) for a wealth of free information, including aerial images and the digitized County Soil Surveys. Another site is the Florida Department of Environmental Protection Land Boundary Information Systems (LABINS) at www.labins.org. This site has excellent, reasonably current aerial images.

\section{Know your objective}

Decisions should be made within the framework of welldefined goals. Therefore, consider:

- Scion Cultivar. Like the rootstock, the cultivar selected represents a choice not often or easily changed after planting.

- Market. Juice quality (mainly soluble solids or sugar content) has often been less important than yield based on field research if the fruit is for processing; however, that scenario has changed with the presence of HLB in Florida, thus affecting the choice of rootstock. With historically high prices for pound-solids, the combination of high yield with high solids is desirable. If the fruit is for fresh market, the influence of the rootstock on external quality and size may be more important.

- Solid-set or Replanting. Sometimes for replanting, a different rootstock than the one originally selected for a solid planting is appropriate. When the replant space is small, choosing a rootstock for its vigor and productivity in the small space becomes more important than other characteristics. Resetting versus replanting has also taken on new meaning in the post-HLB era. Most grower face financial decisions related to making that choice partly because of the common observation that the psyllid insect vector of HLB tends to not penetrate reset groves to the same degree as in replanted groves. The psyllid apparently tends to remain at higher levels near the edges of the reset groves.

\section{Know the rootstocks}

There are readily available sources of information about rootstocks. Each provides a different perspective.

- Experience. Strongly consider planting trees on rootstocks for which you have had positive experiences. The performance boundaries of trees on a particular rootstock are established from years of commercial use. Confidence (and less risk) is derived from that practical experience; however, more risk might be encountered if the decision is made to plant outside the boundaries of the rootstocks with years of field data and grower experiences. Today, in the post-HLB era, there is limited experiences to reply on so other criteria must be used along with accepting greater risk.

- Rootstock Compatibility. Many rootstocks are hybrids of trifoliate orange. There may be compatibility issues expressed at the bud union, as experienced with Murcott on Carrizo. Rootstock compatibility is a particularly important but largely unknown aspect of rootstocks released in recent years.

- Field Experiments and Research Data. Rootstock research functions mainly to determine the commercial potential of new rootstocks, and to ensure that the capabilities and limitations of currently used rootstocks are completely and clearly understood. The various field experiments established for their purpose, including those in commercial groves, represent essentially the only source of publicly available data regarding new rootstocks. The UF/IFAS Plant Improvement and USDAARS Citrus Rootstock teams also present up-to-date data about rootstock field trials available at https://citrusresearch.ifas.ufl.edu/rootstock-field-data and https:// citrusrootstocks.org, respectively.

- Citrus Rootstock Selection Guide, 4th Edition. A substantially revised edition that now describes the traits of 48 rootstocks is available at https://edis.ifas.ufl.edu/ hs1260 and online as an interactive web version at http:// flcrsg.com. Interested parties are strongly encouraged to visit the web version because it offers a considerably expanded opportunity to interact with the rootstock information. The Selection Guide is supported by over 100 downloadable citations related to rootstock and trait. Furthermore, users of the web version can query the tabulated and background information via customized searches. Users should open http://flcrsg.com and click Expert System in the upper menu or Link to Expert 
System in the landing page. A series of screens will appear to assist you in selecting your specific situation. The line of questioning is determined on a case-by-case basis depending on how the interview develops. The system uses its rules to match and score their input against the 1,008 possible factors in the guide (combination of 21 traits and 48 rootstocks). The user is presented a report with a ranked list of rootstocks that on average are top candidates for their situation. $100 \%$ means a good match, while a result closer to $0 \%$ indicates the opposite. The rankings are based on a "Selection Score" (not a statistical value), referring to a relative ranking of the expert system's confidence score suggesting rootstocks suitable for the site situation described during the interview process. The expert system does not keep or archive information provided by users, but users can print a copy of the report.

\section{Choose the rootstock}

The information-gathering processes described above provides a sound foundation for this final step, but it is also good to recognize from the outset that all rootstock decisions are tempered by the absence of any perfect choices. The relative importance given to individual rootstock traits affects rootstock choice. In Florida, rootstock selection is generally based on a combination of concern for productivity and tree survival. "Productivity" for juice fruit can be defined as the maximum quality of juice or soluble solids with the minimum number of risks at the lowest cost. Therefore, priority is normally given to rootstock effects on volume of fruit while maintaining acceptable pound solids per box.

Realistic bottom line? Making profitable rootstock selections essentially involves developing a composite assessment of a rootstock based on its individual characteristics, and then choosing the rootstock that best matches your interest and goals. No one rootstock is likely to be entirely satisfactory in any set of circumstances.

Today, to survive and be profitable, it is essential to consider two factors: [1] Horticultural, site, and pest and disease characteristics; and [2] HLB response. Those two factors can be combined in ways that offer substantially different outcomes;

1. Good horticultural traits-poor HLB response

2. Average horticultural traits-poor HLB response

3. Average horticultural traits-good HLB response
4. Good horticultural traits-good HLB response

How would you rate these combinations? Number 4 is clearly the most desirable; Number 3 might be okay; Number 2 is unacceptable; but what about Number 1 ?

Another realistic bottom line? Plant your own rootstock trial. It is easy to do, easily managed, and your best decision-making tool. For more information about Rootstock Field Trials, visit http://blogs.ifas.ufl.edu/crec/2020/05/20/ lessons-learned-while-conducting-rootstock-field-trials/?fb clid=IwAR1yeuZXNlHG3_2VkiaiWhp920BPOFodjLgbI_4 vrGQz7vRTTnPugeHRaKE. 